Article

\title{
Brexit, Babylon and Prophecy: Semiotics of the End Times
}

\section{Steve Knowles}

Theology and Religious Studies Department, University of Chester, Chester CH1 4BJ, UK; s.knowles@chester.ac.uk

Received: 29 October 2018; Accepted: 28 November 2018; Published: 3 December 2018

\begin{abstract}
This article examines the predilection some Christian premillennialist preachers and teachers have with the semiotic association of geopolitics and biblical prophecy concerning the end times. This was epitomised in the run up to the United Kingdom's referendum on continued membership of the European Union in June 2016. Since its inception, many premillennialists have interpreted the European Union as the place where the Antichrist emerges. Material objects associated with the European Union such as architecture, sculptures, currency and even posters, have been routinely highlighted as providing clear signs of the coming eschaton. Prophetic links between the European Union and satanic agencies, purported to be behind the ambition for an expanding European confederacy, ensured that many premillennialists voted to leave the European Union or were advised to do so in light of such prophetic signifiers. Utilising Webb Keane's notion of representational economies, I argue that a premillennialist representational economy drives the search for signs in the everyday, and specifically those associated with the European Union. In this case, such semiotic promiscuity ratified the need to leave the European Union.
\end{abstract}

Keywords: Brexit; prophecy; premillennialism; European Union; semiotics; Webb Keane

\section{Introduction}

When Mark Carney, the Governor of the Bank of England, gave his post-Brexit statement in an attempt to calm nerves in the immediate aftermath of a seismic shift in European politics, his speech addressed the sense of uncertainty that hovered over the United Kingdom (UK). He spoke of a trinity of uncertainties that affected the economy: geo-political, economic and policy. All of them fed into what he described as "living in times of considerable uncertainty" ${ }^{1}$. The context for the governor's statement was the UK economy and the interim fiscal policies related to leaving the European Union. It was an attempt to calm the financial markets and a tactic designed to send out the 'right signs' that would encourage confidence in the UK economy.

For many social commentators, cultural uncertainty in Western society is not new but has been an underlying theme, particularly over the last 70 years: since the end of the Second World War. Uncertainty and contingency are the hallmarks of living in what has been termed late modernity ${ }^{2}$.

Not everyone, however, views such developments with the kind of caution often associated with sociological analysis on the late modern condition. For Christian fundamentalists who hold to a premillennialist ${ }^{3}$ apocalyptic eschatology, that same uncertainty is interpreted in an entirely different

1 Carney's speech was delivered on 24 June 2016. Full speech at http:/ / www.bankofengland.co.uk/publications/Documents/ speeches /2016/speech915.pdf (accessed on 10 October 2016).

2 See (Giddens 1990, 1991; Beck 2009; Alexander 2013; Knowles 2014).

3 Premillennialism is a pessimistic view of humanity and the world, which anticipates the imminent return of Christ prior to his millennial rule. In the United Kingdom they are predominantly found within Brethren, Baptist and Pentecostal traditions. 
fashion. Whereas, uncertainty has become a consistently applied trope for describing the flux of everyday life in Western society, premillennialists paradoxically seek to find assurance and stability in that very same turbulent and unsettled climate. Indeed, the trinity of uncertainties Carney referred to are actually understood as the 'right signs' from a premillennialist perspective because they point to the 'end times's .

Signs are extremely important for premillennialists. Interpreted through the prophetic texts of the Bible, they act as a barometer for the proximity of Christ's return ${ }^{5}$. Catastrophic events in the form of terrorist attacks, international financial collapse, tsunamis and mass immigration are some of the more significant indicators, or signs, that point to the world being in the end times ${ }^{6}$. That said, not all signs of the end times are as exceptional as some of those listed above. There are indicators to be found in the quotidian and mundane objects and symbols of society that the end times are upon us. This paper focuses on some of these examples in relation to a larger prophetic narrative within the premillennialist apocalyptic eschatological narrative framework-the European Union. I examine how material things such as architecture, posters and sculptures are part of a system of signs that form what the anthropologist Webb Keane refers to as a 'representational economy' of, in this case, the premillennialist prophecy narrative framework ${ }^{7}$. Moreover, the materiality of such examples is vitally important because acknowledging "[a] materialized study of religion begins with the assumption that things, their use, their valuation, and their appeal are not something added to a religion but inextricable from it" ${ }^{\prime \prime}$. It is particularly apparent in the study that follows that without signs, symbols, and tangible material reference points, prophecy would be mostly redundant.

Drawing on data gathered from leading premillennialist figures in print and open access digital media, I argue that the premillennialist apocalyptic ideology—sustained by a predilection for the semiotic association of geopolitics and biblical prophecy-ultimately contributed to the rejection, by UK premillennialists, of continued membership of the EU in the referendum held in June 2016. Using Keane's notion of representational economy and associated semiotic concepts, two examples will be considered which have become focal points for the premillennialist rejection of the $\mathrm{EU}^{9}$.

\section{Key Aspects of Premillennial Apocalyptic Eschatology}

Premillennialist pastors and teachers in the UK took a close interest in the build up to the EU referendum. In sermons up and down the country they were providing what they saw as the biblical case for leaving the $\mathrm{EU}^{10}$. Principally, this is because the $\mathrm{EU}$, in the premillennialist prophetic narrative framework, is associated with the emergence of the Antichrist foretold in the Bible. Prophecies concerning what is referred to as the revived Roman Empire have a strong correlation with the contemporary union of nation-states in Europe, and the European Union is understood to be the fulfilment of such prophetic conjecture.

Premillennialists are defined by their interest in the end times with the term referring to Christ's return (Second Advent) and his subsequent one thousand year reign over all the earth ${ }^{11}$.

\footnotetext{
Economic catastrophe is considered to be a sign of the end times.

See (Knowles 2013).

See (Knowles 2014).

(Keane 2007, p. 18)

(Meyer et al. 2010, p. 209).

There are numerous examples that could have been selected including: EU anthem, EU currency, EU flag.

10 A snapshot of the interest generated by the referendum in terms of sermons preached on the subject can be gleaned on the conservative Christian website and app sermonaudio.com, which describes itself as "The largest and most trusted library of audio sermons from conservative churches and ministries worldwide". (accessed on 13 November 2018). In terms of contributions from the United Kingdom, this website is populated with sermons from mainly conservative Baptist and Brethren congregations.

11 See Revelation 20.
} 
The premillennialists who are the focus of this paper are known as pretribulation premillennialists ${ }^{12}$. Most adhere to what they describe in the vernacular as a 'plain' reading of the biblical text, common among fundamentalist groups ${ }^{13}$. This is not the same as a literal interpretation of the text, though it is often conflated with it.

The doctrine of the 'secret rapture' is key to their eschatological framework ${ }^{14}$. This is the expectation of an any-moment and imminent return of Christ ${ }^{15}$ to take all believers-living and dead-away from the world. The event of the rapture is the harbinger for numerous catastrophic events which take place during a seven-year period known as the Great Tribulation. Christ removes Christians from the earth (in the rapture) leaving only Jews and non-Christians behind ${ }^{16}$. During this time the Antichrist emerges initially heralding world peace, signs a covenant with Israel and forms a government. However, the peace does not last and within this short period cataclysmic events unfold including world wars, famine, and natural disasters which culminate at the end of the seven years in the Battle of Armageddon ${ }^{17}$. Christ then returns triumphant, defeats Satan and establishes a one-thousand-year reign of peace. After the millennium Christ judges all of humanity and establishes a new heaven and new earth ${ }^{18}$.

\section{Key Biblical Texts}

The primary biblical texts used to support the links between the EU and the Antichrist are the books of Daniel and Revelation. In Daniel chapter 2, Daniel interprets the dream of King Nebuchadnezzar of Babylon. The dream centres upon a statue made of five different components ${ }^{19}$, and is initially interpreted as referring to four world powers and their fate. The feet of iron and clay which emerge from the fourth, or old Roman Empire, are what Bible prophecy teachers regard as representing the revived Roman Empire-the fifth empire-from which the Antichrist emerges in the end times. The ten toes of the feet of the statue are made from iron and clay: two materials that do not readily meld together and hence, are inherently weak. Contemporary (pretribulational) premillennialists believe this signifies the current, perilous state of the contemporary European Union, which is purported to be the revived Roman Empire. The clay is understood to represent democracy, whilst the iron is totalitarian rule ${ }^{20}$.

Similarly, in Daniel chapter 7 there is the description of one of Daniel's dreams in which a beast with ten horns arises. The horns represent ten kings (nations) who form a union and from these ten nations will arise one individual who will have control over them ${ }^{21}$. The individual is the Antichrist, who, in gaining authority over the ten will oust and overthrow three of them. The ten horns and the ten toes are identified as the Antichrist's confederacy which culminates in eventual world domination. This is often linked with Revelation 13 where a beast emerges from the sea with ten horns, which are purported to correspond to the ten toes of the statue in Daniel chapter 2, as well as the ten horns

12 Premillennialism can be broadly divided into two groups: historicist premillennialism, those who believe Christ will return after the tribulation; and futurist premillennialism-those who believe Christ will first rapture believers prior to the tribulation and then return after it to reign for a millennium, hence pretribulation.

13 See (Ammerman 1987; Crapanzano 2000; Marty and Appleby 1991).

14 The following biblical texts are central to this doctrine: John 14:1-4; I Cor 15:51-58 and I Thess 4:13-18.

15 This is not to be confused with the second advent of Christ and is sometimes referred to as the doctrine of the Secret Rapture. See (Sweetnam 2006).

16 Jews are purposely identified here as separate to non-believers as premillennialists understand the Jews to have a significant role in the end times due to being God's covenant people.

17 Catherine Wessinger refers to this form of millennialism as catastrophic millennialism due to the pessimistic view of human nature and society. See (Wessinger 2011, p. 5).

18 This is a generic futurist premillennial prophetic framework that virtually all premillennialists would concur with; however, there are many nuanced differences among premillennialists within this general pattern. See (Carpenter 1997, pp. 247-48) for a brief overview.

19 They are: gold for Babylon; silver for the Medo-Persians; bronze for the Greeks, and iron for the Roman Empire. Iron and clay constitute the confederacy of nations in Europe.

20 See (James 2000; Grey 2013; Huckaby 2015).

21 See Daniel 7:8, 24; cf. Revelation 13:1-10. 
of the beast of the alleged Roman Empire in Daniel chapter 7. It is this prophetic hermeneutic that drives the expectations of many premillennialists. Thus, any treaty, collaboration or union among European nations has often been treated with, on the one hand deep suspicion and on the other, a barely tempered excitement due to belief that biblical prophecy is being fulfilled ${ }^{22}$. Indeed, the re-forming of the revived Roman Empire in the guise of the EU is generally understood to be the second most important fulfilment of prophecy after the founding of the modern state of Israel in 1948.

\section{A Premillennialist Representational Economy of the Prophetic}

Keane's notion of representational economies is central to this analysis as it provides a framework within which we can think about "the dynamic interconnections among different modes of signification at play within a particular historical and social formation"23. Further, "The idea of representational economy is meant to situate words, things and persons (along with other agentive beings such as spirits) dynamically within the same world with one another" ${ }^{24}$. It is a way of identifying the assumptions that particular communities or groups might have about certain goods or objects and how they then understand and interpret them within that setting. Closely linked to the notion of representational economy is that of semiotic ideology. "The different elements of a representational economy are subject to different causal logics and temporalities" 25 , and governed by semiotic ideologies, which are the "background assumptions about what signs are and how they function in the world" 26 . Keane notes:

By semiotic ideology I mean people's background assumptions about what signs are and how they function in the world. Such assumptions help determine, for instance, what people will consider the likely role that intentions play in the signification to be, what kinds of possible agent exist to which acts of signification might be imputed, whether signs are arbitrary or necessarily linked to their objects, and so forth ${ }^{27}$.

They are formed between agentive subjects and the object which is acted upon by the agent. Thus, in this context, semiotic ideologies are the result of reflections on that which comprises the premillennialist prophetic representational economy. It is a form of guidance and a way of organizing the semiotic forms that are part of that specific economy of signs.

Another important aspect is the notion of indexicality in relation to representational economies. Indexicality refers to the connections and configurations of signs with one another. An index is something that points to/signifies or infers the signified, that which is the object. The work of the philosopher Charles S. Pierce is influential on Keane's understanding of semiotics. Pierce describes indexicality in the following way:

A weathercock is an indication, or index, of the direction of the wind; because, in the first place, it really takes the self-same direction of the wind, so that there is a real connection between them, and in the second place, we are so constituted that when we see a weathercock pointing in a certain direction it draws our attention to that direction, and when we see the weathercock veering with the wind, we are forced by the law of the mind to think that direction is connected to the wind ${ }^{28}$.

We will see that there are material objects that are signs which point to the end times and which indicate, or provide indexes for its imminence. They act as weathercocks indicating the proximity

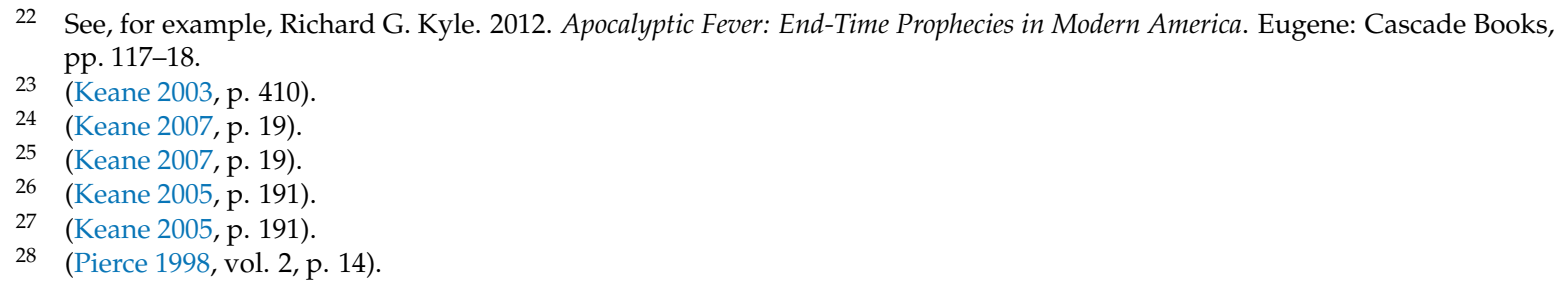


of, and from where the Antichrist will emerge-pointing to the apocalyptic events which follow. Importantly, "the action of indices depends upon association by contiguity, and not upon association by resemblance or upon intellectual operations" ${ }^{\prime 29}$. Indexes, which at first sight, have no apparent connection with apocalyptic ideology actually signal its presence.

\section{Demonic Materiality and Signs of the End Times}

Within this prophetic representational economy, there exists the binary distinction between good and evil: the God of the Bible and Satan, who has a temporary hold and influence on this world. The objects that are recognised as being of a prophetic nature, as signifiers, are not always necessarily representative of divine intervention or activity; on the contrary, the symbols and material examples analysed here are what I describe as instances of demonic materialism.

As alluded to earlier, the notion of a revived Roman Empire dominates contemporary premillennialist prophetic conjecture and it is from here-symbolically as well as geographically-that the Antichrist emerges. The Antichrist then goes on to manipulate and influence political affairs in Europe and further afield. Prior to his unveiling, for premillennialists, his potency and scheming is readily tangible in terms of an ongoing spiritual warfare against Christianity and the diffusion of widespread political turmoil in Europe itself. The representational economy that constitutes the prophetic premillennialist apocalyptic eschatological framework includes both the divine and the demonic; however, what is important in terms of deciphering the imminence of the end times is the rise of what is perceived to be demonic activity and influence and how it is signified.

Keane notes that "where belief is crucial it must take material form ... Ideas are not transmitted telepathically. They must be exteriorised in some way, for example, in words, gestures, objects or practices" ${ }^{\prime 30}$. Keane's observations are important for understanding the relationship of belief in prophecy to the recognisable material manifestations that affirm the prophetic. Prophecy is about signs. They point to future events, the coming to pass of which are discernible in material things, in bricks and mortar, in steel and glass, in currency and in cotton flags. Demonic activity is readily identified, evidenced and exteriorised in the concrete objects of the material to which we now turn.

\section{Manifestations of Demonic Materiality}

From a premillennialist perspective, there has always been suspicion regarding the EU, due, as we have seen, to their particular understanding and interpretation of prophetic texts in the Bible. In its early iterations, in 1949 just after the Second World War, Paul-Henri Spaak, former Prime Minister of Belgium and acknowledged as one of the original founders of the EU, was reported to have said:

We do not want another committee. We have too many already. What we want is a man of sufficient stature to hold the allegiance of all people, and to lift us out of the economic morass in which we are sinking. Send us such a man and, be he god or the devil, we will receive him ${ }^{31}$.

This quotation has been used many times by premillennialists to emphasise the ulterior motives that lie behind the scenes of EU officialdom. However, I have been unable to find evidence of Spaak having actually uttered the quote attributed to him, which, it seems, has developed into something of an urban myth within premillennialist prophetic discourse. Regardless of their legitimacy, these words have served to generate what Richard Landes has termed "semiotic arousal"32. Indeed, in this context,

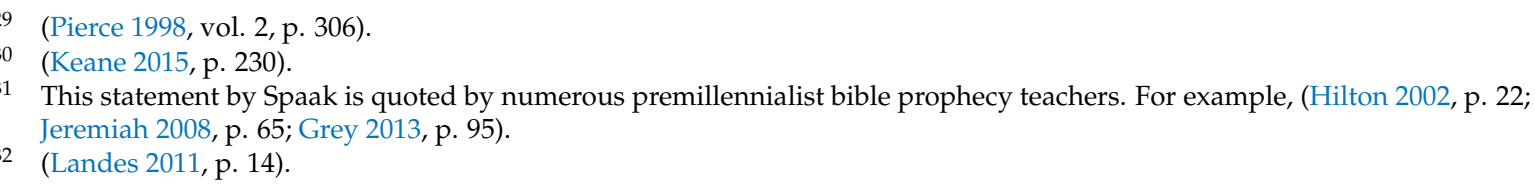


'semiotic promiscuity' would seem to be a more suitable description for the intensification of prophetic sign searching since Spaak allegedly uttered those words.

Consequently, numerous signs have been identified which together provide evidence that the EU is the prophesied revived Roman Empire. Among them are: the Louise Weiss building in Strasbourg, France-home of the European parliament; the currency of the EU—-the Euro; the sculptures outside the European Union buildings in Strasbourg and Brussels-The Removal of Europa and Europa Riding the Bull, the flag of the EU and even the EU anthem. There are more but the focus will be limited to architecture and sculptures.

\subsection{Louise Weiss Building in Strasbourg}

When the Louise Weiss building in Strasbourg, France-home of the European parliament-was completed in 1999, its structure caused something of a stir. Designed by Paris-based architects Architecture Studio Europe, and constructed at a cost of some 470 million euros, the centrepiece consists of a $60 \mathrm{~m}$ tower that intentionally appears to be unfinished on the eastern side. The rationale for the design was to signify the fact that no eastern European country had joined the EU at the time of completion; it symbolised the unrealised dream of a unified Europe.

The building's purpose as the new home of the European parliament ensured scrutiny of the design from some unexpected quarters. Among them were conspiracists from various anti-globalisation movements and religious fundamentalist groups. Premillennialists, who belong to the latter category, did not buy in to the official narrative of why the tower was designed in such fashion. On the contrary, many believed that the structure was actually modelled on the painting, The Tower of Babel (1563), by the Dutch renaissance painter Pieter Bruegel (1525-1569). The significance of this is not so much in the similarity that the Louise Weiss building might have to Bruegel's depiction of Babel per se; rather, it is the identification of the EU parliament building with Babel (Babylon) ${ }^{33}$ and what that represents that is purported to be symbolic of a more sinister influence. What compounded this theory was that 7 years earlier, in 1992, the European Council ${ }^{34}$ had circulated a poster depicting an image very similar to Bruegel's Tower of Babel complete with a construction crane inside the perimeter signifying the continuing construction of the tower. The maxim that accompanied it was "Europe: Many Tongues One Voice". The poster caused outrage among Christian groups and it was quickly removed from public circulation, allegedly due to their complaints ${ }^{35}$.

The reasons for the outrage generated by the image can be traced back to the way many Christians understand the story of the Tower of Babel found in Genesis chapter 11. The narrative describes the "whole world as having one language and a common speech" (11:1), who decide to build a city with a tower that "reaches to the heavens, so that we may make a name for ourselves and not be scattered over the face of the earth" (11:3-4). The story describes how God, seeing the ambition of the people, scatters all the people and their language, resulting in them no longer being able to understand each other ${ }^{36}$. From a premillennialist perspective, this has been interpreted to serve as a warning to humanity not to challenge God. However, the European Council poster was seen as a maleficent example of Europe setting itself up against God. Alan Franklin, UK-based journalist-turned Bible prophecy teacher noted that the poster "appears to be an attempt to reverse God's judgement on Babel"37.

The maxim accompanying the image confirmed to premillennialists that the EU was trying to provide a platform to challenge God. "Europe: Many Tongues One Voice", although appearing to be

33 Babel and Babylon are essentially the same place.

34 The European Council is distinct from the European Union. Whilst the latter refers to the confederacy of member states that constitute the EU, the European Council is the body that defines the EUs overall political strategy and policies. See the EC website http:/ / www.consilium.europa.eu/en/european-council/ (accessed on 15 March 2017).

35 This has been reported on a number of conservative Christian web sites; however, they provide no evidence that the removal of the poster was due to protests by Christian groups.

36 Gen 11: 7.

37 See (Franklin 2003). 
an inversion of the original, is interpreted as actually attempting to re-create the notion of 'speaking as

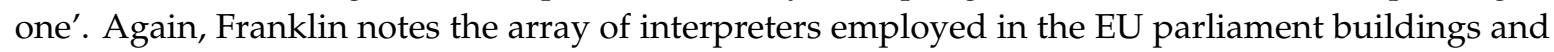
suggests that one voice or understanding is being created by other means with the same result ${ }^{38}$. David Hathaway, itinerant speaker and founder of Eurovision Mission to Europe asked, "is the EU the spiritual development of the original Babel, and is the EU attempting to build what God once destroyed?" 39

In terms of semiotic ideology, within this economy of signs, Babel/Babylon represents rebellion against God and symbolises a marginalisation of worship of the one 'true' God. Thus, in light of the suspicions highlighted above, the construction of the Louise Weiss tower signifies a conjoining of EU agency along with, but under, demonic influence. In the context of the criticism with which the 1992 poster was met, it was absurd, in the mind of premillennialists that the design of the physical building went ahead replicating the form of Bruegel's original. However, on the other hand, it fits with the prophetic narrative framework. It is part of the paradoxical nature of the premillennialist prophetic representational economy. It signifies that the EU is an instrument of more sinister powers: namely those that are satanic. Hathaway claims that not only does Louise Weiss building represent the Tower of Babel externally, the interior resembles that of the Colosseum in Rome. The significance of this should not go unnoticed and it is something to which we will return.

The notion that Babel/Babylon represents a system of government raised in opposition to God is not only significant in the representational economy of premillennialist prophecy narrative framework but highlights how such economies often interact with others in any given social context. The representational economy of international European politics identifies the Louise Weiss building in a very different way to that of premillennialist Christians. The tower is occupied by the offices of civil servants. It is a place where the European parliament meet every month in the cosmopolitan city of Strasbourg, France. For MEPs it is a place to debate the minutiae of EU policy. As well as a place of business, it is open to the general public to view and has cafeterias and refreshment areas. On the other hand, within the premillennialist representational economy, the building represents all that is wrong with the EU. Its design epitomises a flagrant revolt against God and thus is inspired by Satan. Importantly, due to its geographical location (i.e., the headquarters of European politics) it fulfils biblical prophecy.

\subsection{The Woman and the Beast}

Outside the Winston Churchill EU building on Avenue du President Schuman, Strasbourg, is a sculpture of a woman riding on a bull entitled The Removal of Europa ${ }^{40}$. The statue represents the ancient Greek myth of the abduction of Europa by Zeus, and was a gift from Crete to the European Parliament in 2005. The association of Europe with the symbolism of a woman and a bull (beast) has a long history. Europe takes its name from Europa and this symbolism can be found adorned on many artefacts associated with the continent of Europe and, more recently, the European Union. As well as this statue, there is a similar one outside the Justus Lipsius building in Brussels-Europa Riding the Bull. Another example is located inside the Paul Henri Spaak EU building in Brussels where the glass facade inside the dome is covered with a 150 square meter large ceramic mural called Miti del Mediterraneo, which portrays the abduction of Europa and other elements of Greek mythology ${ }^{41}$. As well as appearing together on the Greek and Italian two Euro coin, the images of Europa and of

\footnotetext{
(Franklin 2003, p. 47).

See (Hathaway 2006)

40 It was created by the Greek brothers Nikos and Pantelis Sotiriadis. It weighs almost 6 tons and combines three materials: steel (the bull), bronze (the girl), and glass (the back of the bull). See http:/ / en.strasbourg-europe.eu/discover-artisticeurope,36299, en.html (accessed on 10 March 2017).

41 Designed between 1992 and 1993 by Aligi Sassu.
} 
the bull appear separately on various EU documents. For example, the bull features on EU residency permits, and the new Europa series of bank notes features an image of Europa ${ }^{42}$.

For EU officials, adopting such symbolism might be regarded as mundane and non-controversial in the secular environment of the political representational economy of the EU: it is symbolism that links the old Europe with the building of a new, stronger and united Europe. There is a quite different perspective when understood within the representational economy of premillennialist prophecy. The semiotic ideology governing the functional qualities and meanings of signs within the prophetic representational economy reflect very different connections in terms of what Europa and the bull actually denote.

Tony Pierce, a leading British premillennialist teacher and contributor to Prophetic Witness ${ }^{43}$ magazine, notes:

The EU has adopted symbols straight out of the Book of Revelation. Outside the Council of Europe building in Brussels there stands a statue of Europa (a woman) being carried off by a bull, a picture of the Greek myth of the Rape of Europa. In other words, it is a woman riding a beast. Revelation 17.1-6 sees a woman riding the beast as the symbol of false religion allied to the antichrist political power, persecuting true believers in Jesus ${ }^{44}$.

The semiotic ideology, the assumptions guiding how such signifiers should be interpreted, connects the physical presence of the sculpture with the symbolism found in the texts of the book of Revelation and specifically chapter 17 . What is significant is the association of the woman riding the beast as a symbol of 'false religion' who, in turn, is allied to the Antichrist. The reference is generally understood in this economy of signs as the 'apostate church' (Rev 17). The woman depicted here is identified as a harlot (v.1). In verse 5 her full title is given: "Mystery Babylon the Great, Mother of Harlots, and of the abominations of the earth". The clues to what church this might symbolise are found at the end of the chapter. Verse 18 states, "The woman you saw is the great city that rules over the kings of the earth". Many premillennialists believe this to refer to the city of Rome: the hub of Europe which dominated the known world at the time that Revelation was written. Furthermore, the connection is made that the church associated with Rome is the Roman Catholic Church and its dominant position as a world religion.

In a sermon delivered two weeks prior to the UK referendum, David Moore, a Baptist minister in the UK claimed that the woman in Revelation 17 represents the Roman Catholic Church and her global influence. He stated,

When you think about spiritual entities, religious organisations that have this extent of presence, that has this amount of political sway, that has this degree of prosperity, that practices a religion that presents itself as Christianity but actually in practice is blasphemous and abominable, there is only one religion on earth that fits the bill ... I'm speaking to you about Roman Catholicism ${ }^{45}$.

If more evidence were needed that the Roman Catholic Church represented the apostate church, Moore identified a further link in the colours described in Revelation 17:4. The woman is described as "dressed in purple and scarlet ..." Moore was quick to point out that

Even the colouring [of the woman] here, the purple and the scarlet. Google the Holy See. Have a look at the images that come up. You'll see them sitting there and you will find them arrayed in two colours: purple and scarlet.

42 https://www.ecb.europa.eu/euro/banknotes/europa/html/index.en.html (accessed on 10 March 2017).

43 Prophetic Witness is the magazine of the oldest premillennialist organization in the world. Founded in 1917 by Frederick B. Meyer it has recently celebrated its centennial year. Approximately 1500 magazines are distributed each calendar month mainly in the United Kingdom to independent Brethren, Baptist and Pentecostal church members.

44 https://lightforthelastdays.co.uk/articles/events-in-europe/eu-prophesied-bible/ (accessed on 10 March 2017).

45 (Moore 2017). 
Moore finds clear connections between the woman (the harlot) and the Roman Catholic Church. It is a view that is common within the representational economy of premillennialist prophecy. Pastor Ken Davidson of Donaghcloney Elim Church, Northern Ireland, in a passionately delivered pro-Brexit sermon, emphasised the link between the description in Rev 17:4 of the colour of the attire the woman wears, and the vestments of the Roman Catholic Church; even displaying a picture of them ${ }^{46}$.

The symbolism of the woman fits with the premillennialist view of Roman Catholicism, and it is no coincidence that this and the symbolism that adorns high profile architecture and artefacts of the EU resonates so strongly with that found in Bible prophecy. Indeed, as Joseph Webster, in his insightful study of Protestants in a Scottish fishing village, notes that it is 'Godincidence' that replaces coincidence ${ }^{47}$. However, it is the demonic that has temporary influence over the world with the EU being the cradle of the Antichrist.

Davidson, also, among many other examples of what he deemed to be Roman Catholic collusion with the machinations of the EU named some of the leading euro bureaucrats: Jean Claude Junker, Donald Tusk, Frans Timmermans, Martin Schulz, Mario Draghi and Federica Mogherini as all being Jesuits ${ }^{48}$. The point being made with such a lengthy list is that the EU is controlled by a Jesuit (Roman Catholic) cabal. For Davidson, it was part of a conspiratorial attempt to continue to wrestle power away from nation-state members under the guise of the EU. The connections and links that are evident demonstrate what I argue is a demonic lineage that premillennialists trace from the chapters of the book of Revelation through to the contemporary political administration of the EU. The Roman Catholic Church embodies the spirit of the Antichrist and its clandestine influence is a subjugating factor in EU politics ${ }^{49}$.

\section{Prophetic Material Objects and Signifiers}

In the representational economy of premillennial prophecy signs are important. Without signs, symbols and indicators there is no clue as to whether or not prophecy is being fulfilled; no indication as to the proximity of Christ's return. Moreover, without the accompanying semiotic ideologies to assert themselves on material goods and products they do not actually affirm anything. Within this 'economy' the material objects, goods etc. are subject to scrutiny through the semiotic ideologies underpinned by the assumptions and influences of premillennialist apocalyptic eschatology.

The examples analysed here are part of a bigger picture in terms of the way material objects index the end times. They are part of the prophetic end time narrative focussed upon Europe and the formation of the European Union and what that represents-setting the scene for the Antichrist. The prophetic is not just about divine activity or action. The demonic is just as important for discerning the signs of the times. The devil is in the detail and it is within the detail of objects such as sculptures, posters, architecture, and the colour of garments that demonic influence is identified. It is such details that point beyond those objects themselves to the propinquity of the coming apocalypse: "The very materiality of objects is inseparable from their capacity to signify"50. The power of these material objects is made all the more potent by their connection, their indexicality to one another and what they point to beyond themselves. Semiotic ideologies allow for the objectification of signs to be identified as such and then traced in terms of what they signify; they manifest further points of signification.

What is evident from analysis of those objects is that there is a common denominator that demonstrates both commonality and also a processual linkage between the material signs. That signifier is Babylon. If, in the words of the New Testament scholar Ernst Käsemann, "apocalyptic [ism] was the

\footnotetext{
(Davidson 2017).

See (Webster 2013).

All those named are some of the most powerful politicians within the European Council who oversee policy for the EU.

For in depth analysis of attitudes to Roman Catholicism within a Northern Ireland context see (Searle 2014).

(Keane 2006, p. 311).
} 
mother of all Christian theology"51, then Babylon might be regarded as the mother of all apocalyptic signifiers in terms of its importance in this representational economy. Babylon, if not explicitly symbolised, lurks in the shadows of the representational economy of premillennial prophecy.

Starting with The Tower of Babel, this serves first as a symbol of rebellion against God. In Peircean semiotics, a symbol need not have any connection between what it is ontologically, and what it signifies. What it signifies is culturally learned. For Pierce, "a symbol ... fulfils its function regardless of any similarity or analogy with its object and equally regardless of any factual connection"52. Thus, in this sense, a tower reaching up to the heavens symbolically denotes a rejection of God. This understanding has, through instruction and repetition, become a normative myth within the Christian tradition and is the root, or origin, of the processual linkages to the material objects that point beyond themselves to the end times.

The Louise Weiss building is both an icon and an index signifying and representing contemporary Babylon (Babel). It is an icon of the Tower of Babel in terms of imagined similarity, in accord with Pierce's understanding. In premillennialist discourse such iconicity signifies that same rebellion manifest in the original myth. As well as being an iconic object it has indexical qualities, inasmuch as it points to something beyond itself: the proximity of the end times and the notion that the arrival of the Antichrist is close at hand. It has meaning beyond its ontological status and its concrete materiality as a European Union parliamentary building; however, it is also precisely because it is an EU structure that it is an object of demonic materiality, and an object that signifies such presence.

The symbolic nature of the statues of Europa riding the bull (beast) outside prominent EU buildings indexically points to demonic activity. Europa signifies what premillennialists believe to be the apostate church. Linked to 'Mystery Babylon' in Revelation, Europa and the beast signify the Roman Catholic church and invoke powerful symbolism that is interpreted as Roman Catholicism, as counterfeit Christianity in the service of Satan that has infiltrated the hierarchy of the EU.

\section{Conclusions}

What does this all have to do with the referendum on whether the UK should leave the EU? The semiotic ideology that lies within the representational economy of premillennial prophecy interprets European confederacy as the fulfilment of the prophetic texts found in Daniel and Revelation. It is here we find text and contemporary context together generate, in the words of Richard Landes, "semiotic arousal" (Landes 2011, p. 14). The symbolism adopted by the EU serves to affirm and ratify this understanding. This being the case, premillennialist pastors, teachers and leaders were compelled to recommend to their congregations and followers to 'leave' and vote for 'Brexit' ${ }^{53}$. To vote to remain was tantamount to rebelling against God and side with a union that sought to align itself with Satan and the emerging Antichrist. To leave was purposely to distance oneself from the machinations of the $\mathrm{EU}$, as well as to disassociate 'true' believers from the apostate church—Roman Catholicism-Mystery Babylon, the harlot (Europa) and the cabal of Jesuits, who in the echelons of power within the EU, are deemed to be working toward complete control of European nation-states. In the words of Alan Franklin:

The Bible teaches that the Revived Roman Empire of the end times will be a creation of Satan, and out of it will come his representative, the Antichrist. The fact that the formation of the European Union has major spiritual implications is reflected in the religious symbols that the Union has adopted in the form of its flag, its anthem, its architecture, and its basic $\log 0^{54}$.

\footnotetext{
(Käsemann [1960] 1969, p. 102).

(Pierce 1998, vol. 2, p. 163).

See also (Knowles 2018).

4 (Franklin 2017). See also Prophetic Witness April 2016 which contained articles on the dangers of the European Union interpreted through a premillennialist biblical prophecy lens. Tony Pearce, a well-known preacher and teacher in premillennialist circles in the United Kingdom wrote Brexit-A Blow for Global Government. https: / / www.lightforthelastdays.
} 
For premillennialists, Brexit was a necessary rejection of an end time empire that signifies through accretion a lineage of material products pointing to demonic powers that emerge in the end times and produce the Antichrist.

Funding: This research received no external funding.

Conflicts of Interest: The author declares no conflicts of interest.

\section{References}

Alexander, Jeffrey. C. 2013. The Dark Side of Modernity. Cambridge: Polity Press.

Ammerman, Nancy Tatom. 1987. Bible Believers: Fundamentalists in a Modern World. New Brunswick: Rutgers University Press.

Beck, Ulrich. 2009. World at Risk. Cambridge: Polity Press.

Carpenter, Joel. A. 1997. Revive Us Again: The Reawakening of American Fundamentalism. Oxford: Oxford University Press.

Crapanzano, Vincent. 2000. Serving the Word: Literalism in America from the Pulpit to the Bench. New York: New Press.

Davidson, Ken. 2017. Brexit! A Scriptural, Spiritual, Historical and Prophetical look at the European Union. Available online: https:/ / www.youtube.com/watch?v=KyKnHY3coMs (accessed on 16 March 2017).

Franklin, Alan. 2003. EU: Final World Empire. Oklahoma: Hearthstone Publishing.

Franklin, Alan. 2017. Europe in Prophecy/cited by D. Reagan. Available online: http://christinprophecy.org/ articles/europe-in-prophecy / (accessed on 10 March 2017).

Giddens, Anthony. 1990. The Consequences of Modernity. Cambridge: Polity Press.

Giddens, Anthony. 1991. Modernity and Self Identity: Self and Society in the Late Modern Age. Cambridge: Polity Press.

Grey, Erica. 2013. The Revived Roman Empire: Europe in Bible Prophecy. Danbury: Pedante Press.

Hathaway, David. 2006. Babylon in Europe: What Bible Prophecy Reveals about the European Union. Chichester: New Wine Press.

Hilton, Adrian. 2002. The Principality and Power of Europe: Britain and the Emerging Holy European Empire. Rickmansworth: Dorchester House Publications.

Huckaby, Scott. 2015. End Times Evangelism: The Bible Explains the News. Published privately.

James, Edgar C. 2000. Understanding the Prophecies of the Millennium. Chicago: Moody Press.

Jeremiah, D. 2008. What in the World Is Going On? 10 Prophetic Clues You Cannot Afford to Ignore. Nashville: Nelson Books.

Käsemann, Ernst. 1969. The Beginnings of Christian Theology. In New Testament Questions of Today. Translated by W. J. Montague. London: SCM Press. First published 1960. pp. 82-107.

Keane, Webb. 2003. Semiotics and the Social Analysis of Material Things. Language and Communication 23: 409-25. [CrossRef]

Keane, Webb. 2005. Signs are not the Garb of Meaning. In Materiality. Edited by D. Miller. Durham: Duke University Press, pp. 182-205.

Keane, Webb. 2006. Anxious Transcendence. In The Anthropology of Christianity. Edited by Fenella Cannell. Durham: Duke University Press, pp. 308-23.

Keane, Webb. 2007. Christian Moderns: Freedom and Fetish in the Mission Encounter. Oakland: University of California Press.

Keane, Webb. 2015. On the Materiality of Religion. Material Religion 4: 230-31. [CrossRef]

Knowles, Steven. 2013. Rapture Ready and the World Wide Web: Religious Authority and the Internet. Journal of Media and Religion 12: 128-43. [CrossRef]

co.uk/articles/current-issues/light-for-the-last-days-june-2016.html (accessed on 12 February 2018). See also his sermon in which he explicitly advised the congregation to which he was speaking to vote for Brexit. Available through The Bridge Christian Fellowship website http:/ / s3-us-west-2.amazonaws.com/mp3-summer2016/190616e+2+Timothy+3+to+4.8.mp3 (accessed 16 November 2018). 
Knowles, Steven. 2014. Risk or Rapture: Signs of the end or Symptoms of World Risk Society? Culture and Religion 15: 419-35. [CrossRef]

Knowles, Steven. 2018. Brexit, Prophecy and Conspiracy: A Necessary Rejection of an Endtime Empire. Nova Religio 20: 2-28. [CrossRef]

Landes, Richard. 2011. Heaven on Earth: The Varieties of Millennial Experience. Oxford: Oxford University Press.

Marty, Martin. E., and R. Scott Appleby, eds. 1991. Fundamentalisms Observed. Chicago: University of Chicago Press.

Meyer, Birgit, David Morgan, Crispin Paine, and S. Brent Plate. 2010. The Origin and Mission of Material Religion. Religion 40: 209. [CrossRef]

Moore, David. 2017. The European Union in Bible Prophecy. Available online: www.sermonaudio.com (accessed on 13 March 2017).

Pierce, Charles. H. 1998. The Essential Pierce: Collected Philosophical Writings. Bloomington: Indiana University Press, vol. 2.

Searle, Joshua. T. 2014. The Scarlet Woman and the Red Hand: Evangelical Apocalyptic Belief in the Northern Ireland Troubles. Cambridge: Lutterworth Press.

Sweetnam, Mark. 2006. Tensions in Dispensational Eschatology. In Expecting the End: Millennialism in Social and Historical Context. Edited by Kenneth.G.C. Newport and Crawford Gribben. Waco: Baylor University Press, pp. 173-92.

Webster, Joseph. 2013. The Anthropology of Protestantism: Faith and Crisis among Scottish Fisherman. New York: Palgrave MacMillan.

Wessinger, Catherine. 2011. Millennialism in Cross-Cultural Perspective. In The Oxford Handbook of Millennialism. Edited by Catherine Wessinger. Oxford: Oxford University Press.

(C) 2018 by the author. Licensee MDPI, Basel, Switzerland. This article is an open access article distributed under the terms and conditions of the Creative Commons Attribution (CC BY) license (http:/ / creativecommons.org/licenses/by/4.0/). 